\title{
Workability and mechanical properties of concrete with volcanic powder
}

\author{
Huaizhuo Zhang, a , Wenhong Tao ${ }^{1, b}$ and Xinghua $\mathrm{Fu}^{1, \mathrm{c}}$, Mingle \\ $\mathrm{Liu}^{2, \mathrm{c}}$,Shuangshuang $\mathrm{Hou}^{2, \mathrm{c}}$ \\ ${ }^{1}$ School of Materials Science and Engineering, University of Jinan, Shandong, China \\ ${ }^{2}$ GCBM Technology Center, Shenzhen Gangchuang Building Material CO, LTD, Shenzhen, China \\ a923042563@qq.com, bmse_taowh@ujn.edu.cn, cmse_fuxh@ujn.edu.cn
}

\begin{abstract}
Keywords: volcanic powder, water reducing agent, sand ratio, volcanic powder, cement Abstract. In order to keep the balance between construction industry development and environment protection, achieve the sustainable development between economy and the environment. As a part of sustainable development policy, this study aims to replace fly ash with volcanic powder for making concrete. By making volcanic powder mortar to find out the range of optimum mix amount. And study the suitability of replacing fly ash by volcanic powder in producing concrete and find out the influencing rule of water cement ratio, volcanic powder content and sand ratio.
\end{abstract}

\section{Introduction}

The growing needs of material resources and the requirements of environmental protection impels us to use waste material. China has rich volcanic resources and which had been applied extensively in a lot of professions ${ }^{[1,2]}$. Processing volcanic rock produce a large number of volcanic powder in stone factory, abandoned powder pollute the environment. And with the thermal power station decreases, the yield of fly ash will reduce. In addition, making concrete with volcanic powder, $\mathrm{SiO}_{2}$ and $\mathrm{Al}_{2} \mathrm{O}_{3}$ reacts with $\mathrm{Ca}(\mathrm{OH})_{2}$ to form Calcium silicate hydrate $(\mathrm{CSH})$, it can Improve the quality of concrete ${ }^{[3]}$.

As a part of sustainable development policy, in order to solve the shortage of fly ash and Protect the environment and improve mechanical resistances and the durability of concrete, this study use volcanic powders as supplementary cementitious materials for concrete.

\section{Raw Material}

The raw materials of concrete are cement, additive, mineral admixture, fine aggregate and coarse aggregate. These materials are mixed with water, molded and turned to be high strength mixture. The type of Portland cement is P.O 42.5 and which was supplied by China national building material group. In this study, the secondary FA and S95 grade ground slag was used to make cement, which are provided by respectively Shenzhen Mawan Power plant and Shenzhen Xiaoyetian Cement plant. Water reducing agent: polycarboxylate superplasticizer, from Shenzhen Gangwan concrete batching plant, and water-reducing rate is $25 \%$. volcanic rock of the Guangdong was ground at $25 \mathrm{~min}$, specific surface area is $484.57 \mathrm{~m} 2 / \mathrm{kg}$. Fine aggregate: the fineness modulus of river sand was 2.6; Coarse aggregate: continuous gradation gravel, the particle diameters of gravel was $5-25 \mathrm{~mm}$.

Laser Particle Size Analysis.Particle size distribution is an important physical indexes of volcanic powder. The particle size distribution of raw materials have a great influence on the performance of concrete, the volcanic powder fineness were detected by laser particle size analyzer. The results of the particle size distribution are shown in Fig 1. some difficult ground minerals show independent distribution peaks in the coarse particles.

Particle morphology analysis. The particle morphology of mineral admixture has a great influence on the performance of concrete. And the picture of raw materials was obtained via polarizing microscope in Fig 2.

Maintaining the Integrity of the Specifications. The chemical composition of the volcanic indicates a salic mineral. volcanic powder's chemical composition is mainly $\mathrm{SiO}_{2}$ and $\mathrm{A}_{2} \mathrm{O}_{3}$, The content of 
two minerals is above $69 \%$, and chemical composition is great. Volcanic powder would react with calcium hydroxide to form more calcium silicate hydrate. Mixing volcanic powder into concrete would exhibit considerable enhancement in durability properties.
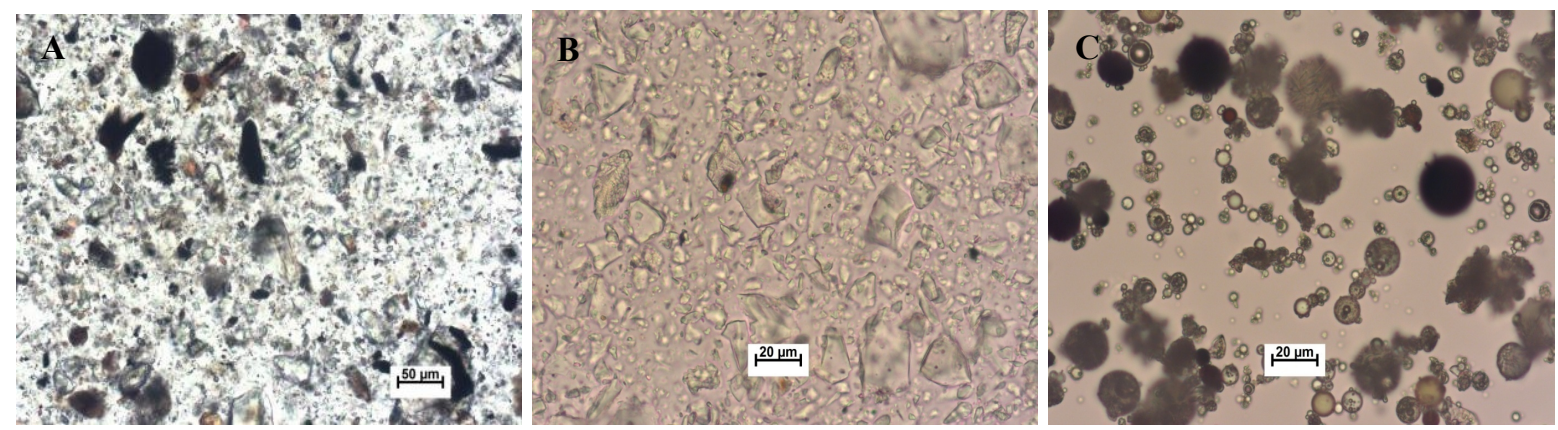

Fig. 1, Polarizing microscope image of volcanic powder(A), slag powder(B), fly ash(C).

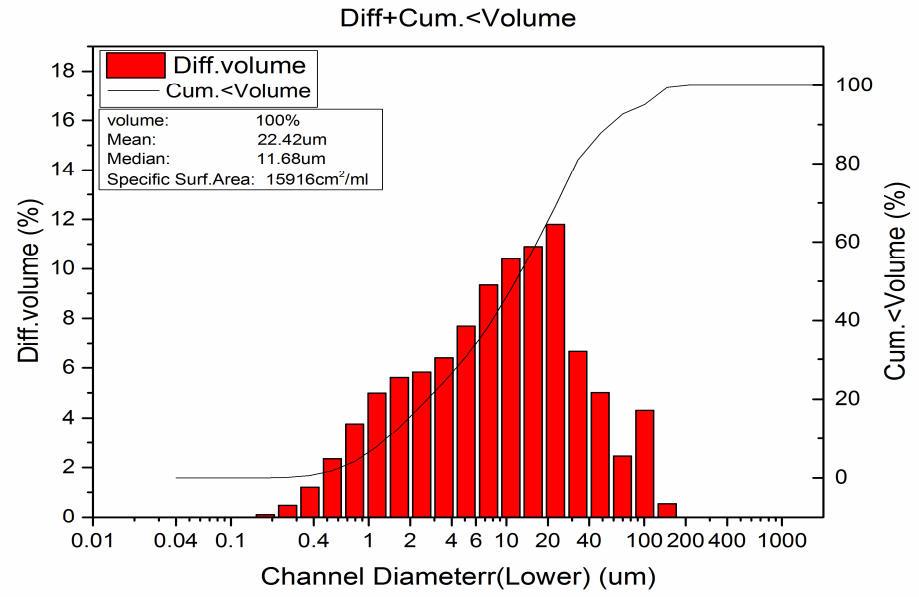

Fig. 2, Laser particle size distribution of grinding $25 \mathrm{~min}$ volcanic powder.

Table 1,Chemical composition of volcanic powder [wt $\%$ ].

\begin{tabular}{lccccccccc}
\hline & $\mathrm{SiO}_{2}$ & $\mathrm{Al}_{2} \mathrm{O}_{3}$ & $\mathrm{CaO}$ & $\mathrm{MgO}$ & $\mathrm{Fe}_{2} \mathrm{O}_{3}$ & $\mathrm{Na}_{2} \mathrm{O}$ & $\mathrm{K}_{2} \mathrm{O}$ & $\mathrm{SO}_{3}$ & Loss \\
\hline $\begin{array}{l}\text { volcanic } \\
\text { powder }\end{array}$ & 50.43 & 16.36 & 8.95 & 4.44 & 9.95 & 4.58 & 1.72 & -- & -- \\
\hline
\end{tabular}

\section{volcanic powder mortar}

As shown in Table 2, find out the range of optimum mix amount through making volcanic powder mortar .

Compressive strength can not indicate the strength contribution of volcanic powder to concrete. Use this formula to find out the range of optimum mix amount ${ }^{[4]}$.

$$
\mathrm{R}_{\mathrm{c}}=\mathrm{R}_{\mathrm{a}} / \mathrm{q}_{0} .
$$


$\mathrm{q}_{0}---$ Percentage of cement in concrete

$$
\begin{aligned}
& R_{j}=R_{c} / 100 . \\
& A=\left(R_{c}-R_{j}\right) / R_{c} * 100 \% / q .
\end{aligned}
$$

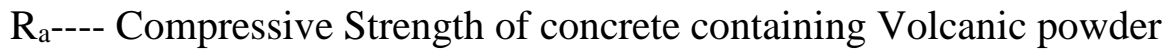

q---Percentage of volcanic powder in concrete 
As The Table 3 shown, the amount of volcanic powder should be less than $20 \%$ in concrete. Table 2, Test results of volcanic mortar.

\begin{tabular}{ccccc}
\hline Number & $\begin{array}{c}\text { Cement } \\
(\mathrm{Wt} / \mathrm{g})\end{array}$ & $\begin{array}{c}\text { Volcanic } \\
\text { powder(Wt\%/g) }\end{array}$ & $\begin{array}{c}\text { Standard } \\
\text { Sands(g) }\end{array}$ & $\begin{array}{c}\text { water cement } \\
\text { ratio }\end{array}$ \\
\hline X0 & $100 / 450$ & $0 / 0$ & 1350 & 0.5 \\
X1 & $90 / 405$ & $10 / 45$ & 1350 & 0.5 \\
X2 & $80 / 360$ & $20 / 90$ & 1350 & 0.5 \\
X3 & $70 / 315$ & $30 / 135$ & 1350 & 0.5 \\
X4 & $60 / 270$ & $40 / 180$ & 1350 & 0.5 \\
\hline
\end{tabular}

Table 3 , strength contribution of volcanic powder.

\begin{tabular}{|c|c|c|c|c|c|c|c|c|c|}
\hline \multirow{2}{*}{$\begin{array}{c}\text { numb } \\
\text { er }\end{array}$} & \multirow{2}{*}{$\begin{array}{c}\text { Volcani } \\
\text { c } \\
\text { powder } \\
/ \mathrm{Wt} \%\end{array}$} & \multicolumn{2}{|c|}{$\begin{array}{l}\text { Compressive } \\
\text { strength/Mpa }\end{array}$} & \multicolumn{2}{|c|}{$\mathrm{Rj}$} & \multicolumn{2}{|c|}{$\mathrm{Rc}$} & \multicolumn{2}{|c|}{ A } \\
\hline & & $7 d$ & $28 \mathrm{~d}$ & $7 \mathrm{~d}$ & $28 \mathrm{~d}$ & $7 d$ & $28 \mathrm{~d}$ & $7 d$ & $28 \mathrm{~d}$ \\
\hline X0 & 0 & 63.83 & 79.48 & 0.64 & 0.79 & - & - & 0 & 0 \\
\hline X1 & 10 & 66.53 & 76.23 & - & - & 0.74 & 0.85 & 1.35 & 0.71 \\
\hline $\mathrm{X} 2$ & 20 & 53.11 & 64.10 & - & - & 0.66 & 0.80 & 0.15 & 0.063 \\
\hline $\mathrm{X} 3$ & 30 & 44.05 & 54.55 & - & - & 0.63 & 0.78 & -0.005 & -0.043 \\
\hline $\mathrm{X} 4$ & 40 & 34.85 & 45.76 & - & - & 0.58 & 0.76 & -0.26 & -0.099 \\
\hline X5 & 50 & 26.44 & 34.7 & - & - & 0.53 & 0.69 & -0.42 & -0.290 \\
\hline X6 & 60 & 19.84 & 20.37 & - & - & 0.50 & 0.51 & -0.47 & -0.4 \\
\hline
\end{tabular}

\section{Results and discussion}

Concrete Grade of Strength design is C40. Using volcanic powder, Water reducing agent and Sand ratio as variable,water cement ratio is 0.39 , content of volcanic powder and slag is $45 \%$. As Figure 6 shown, the amount of volcanic powder was less than $20 \%$. The study used $55 \mathrm{wt} \%$ of cement, 0.39 of water cement ratio. The $28 \mathrm{~d}$ test results are shown in Table 4.

As the Fig 3 shown, effection of various factors on compressive Strength : volcanic powder $>$ Water reducing agent $>$ Sand ratio. With the increase of volcanic powder, compressive Strength decreases. The activity of volcanic powder is lower than slag and which will reduce ompressive Strength. With the increase of sand ratio, compressive Strength decreases initially and increases afterwards. The sand ratio of $45 \mathrm{wt} \%$ is most suitable for the particle size distribution of the concrete. The effect of Water reducing agent on compressive strength is similar to Sand ratio. Too low water cement ratio will increase hydration heat and make the workability worse; Too high water cement ratio will reduce the strength of concrete. The water reducing agent can reduce water consumption, increase strength and save cement dosage. 


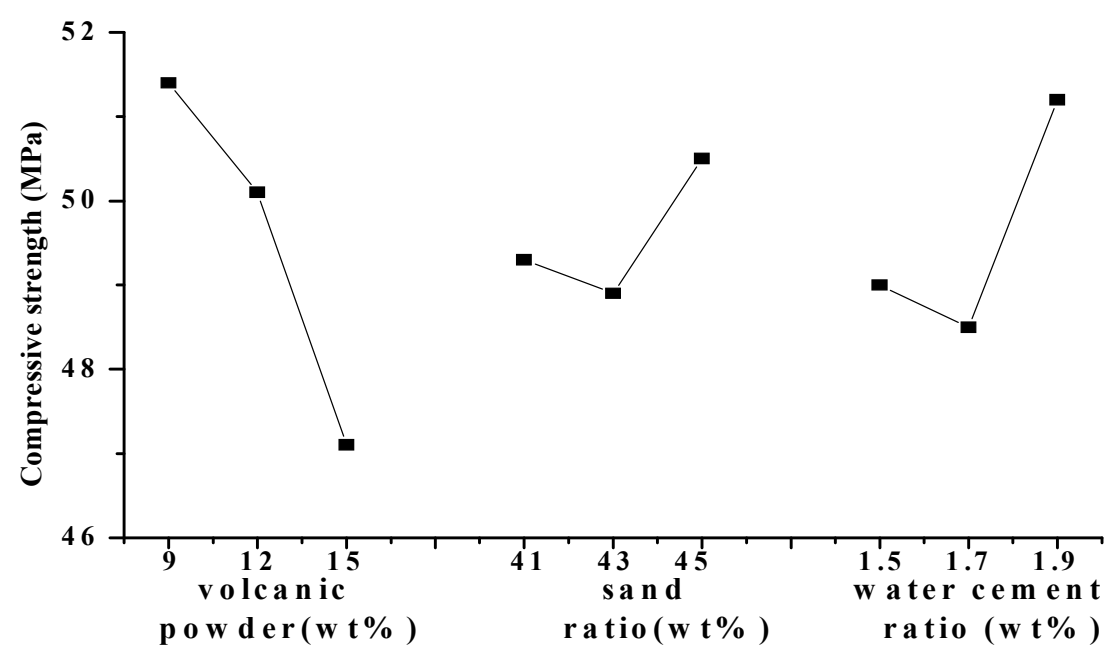

Fig. 3, Effect of various factors oncompressive Strength.

Table 4, The test result.

\begin{tabular}{cccccccc}
\hline Number & $\begin{array}{c}\text { Water } \\
\text { cement } \\
\text { ratio }\end{array}$ & $\begin{array}{c}\text { Water } \\
\text { reducing } \\
\text { agent } \\
(\mathrm{Wt} \%)\end{array}$ & $\begin{array}{c}\text { Cement } \\
(\mathrm{Kg} / \mathrm{m} 3 \\
/ \mathrm{Wt} \%)\end{array}$ & $\begin{array}{c}\text { Volcanic } \\
\text { powder } \\
(\mathrm{Kg} / \mathrm{m} 3 \\
/ \mathrm{Wt} \%)\end{array}$ & $\begin{array}{c}\text { Slag } \\
(\mathrm{Kg} / \mathrm{m} 3 \\
/ \mathrm{Wt} \%)\end{array}$ & $\begin{array}{c}\text { Sand } \\
(\mathrm{Kg} / \mathrm{m} 3\end{array}$ & $\begin{array}{c}\text { Compressive } \\
/ \mathrm{Wt} \%)\end{array}$ \\
\hline R1 & 0.39 & 1.9 & $210 / 55$ & $57 / 15$ & $114 / 30$ & $819 / 45$ & 52.3 \\
R2 & 0.39 & 1.7 & $210 / 55$ & $57 / 15$ & $114 / 30$ & $782 / 43$ & 49.4 \\
R3 & 0.39 & 1.5 & $210 / 55$ & $57 / 15$ & $114 / 30$ & $746 / 41$ & 44.7 \\
R4 & 0.39 & 1.7 & $210 / 55$ & $46 / 12$ & $126 / 33$ & $819 / 45$ & 48.4 \\
R5 & 0.39 & 1.5 & $210 / 55$ & $46 / 12$ & $126 / 33$ & $782 / 43$ & 51.5 \\
R6 & 0.39 & 1.9 & $210 / 55$ & $46 / 12$ & $126 / 33$ & $746 / 41$ & 50.5 \\
R7 & 0.39 & 1.5 & $210 / 55$ & $34 / 9$ & $137 / 36$ & $819 / 45$ & 50.8 \\
R8 & 0.39 & 1.9 & $210 / 55$ & $34 / 9$ & $137 / 36$ & $782 / 43$ & 50.9 \\
R9 & 0.39 & 1.7 & $210 / 55$ & $34 / 9$ & $137 / 36$ & $746 / 41$ & 52.6 \\
\hline
\end{tabular}

\section{Conclusions}

Based on the experimental data, replacement of fly ash with volcanic powder is feasible.The content of volcanic powder in concrete should be less than $15 \%$. The influence of various factors are considerated comprehensivly, volcanic powder content have great influence on compressive strength .And Water reducing agent and Sand ratio have a certain degree of influence.

\section{References}

[1] Labbaci,Y. et al, in: The use of the volcanic powders as supplementary cementitious materials for environmental-friendly durable concrete. edtied by Construction \& Building Materials 133(2017), 468-481.

[2] Zhongwei Wu, in: high performance concrete. edtied by Concrete and cement products, 3-6.

[3] Yusha Li, in: Study on the influence of volcanic powder on properties of cement-based materials in Baoshan area of Yunnan. edtied by Diss. Central South University, 2010. 
[4] Zhiliang Meng, in: Preliminary study on the strength of high volume fly ash concrete at 28 days. edtied by Journal of Agricultural University of Hebei 23.1(2000):82-84. 